\section{On Erasure and Misrepresentation}

\author{
Selena Baugh
}

Sophomore, Sociology/Africology and African

American Studies

Representation is crucial concerning questions of justice and equity. The way a group is perceived by others dictates the way they will be positioned in society. This is a fact which has been modeled consistently throughout history. Those who are perceived as inherently criminal are more likely to be abused by the justice system, as in the case of Black people in the United States, while those who are viewed as inherently weak are less likely to access positions of power, as in the case of women around the world. This pattern illustrates the importance of perception and therefore representation. Mary Wollstonecraft's $A$ Vindication on the Rights of Woman, the Revisionaries documentary, Herodotus' Histories, and the U.S. Constitution all illustrate the ability of a few people to dictate the positioning of various groups in society based entirely on the way individuals represent or misrepresent said groups. Although representation ostensibly implies increased visibility, when the available images are limited, those with platforms can use representation as a means of erasing or subjugating hitherto underrepresented groups.

Throughout history, the groups who have been most susceptible to damaging representation have been those who were unable to effectively represent themselves. This is the case most often with those who possess little social or economic capital and therefore must rely on a select few to speak on their behalf. This lack of voices lends more credence to the few available, which gives those representatives inordinate power over a group's narrative. As a result, a single text which is meant to portray a certain group can effectively set the framework for how those people will be perceived for millennia. Whether that text omits people or misrepresents them, the effects can be disastrous.

One of the most infamous examples of this is Herodotus's Histories, which inadvertently situates Herodotus, a single man, as a sole spokesperson for several civilizations, most of whom do not have the wherewithal to contradict his accounts. As a result, when Herodotus makes claims such as, "[Egypt] has very many remarkable features and has produced more monuments which beggar description than any other place in the world," readers have little choice but to accept this as fact, regardless of the other civilizations around the world at the time which may have been superior (Herodotus 108.) Not only does this place Egypt in a state of superiority over other nations, it effectively erases all other cultures which go unmentioned, thus discrediting them and ignoring their achievements. Furthermore, Herodotus' reference to Egyptian culture as "idiosyncratic" in relation to Greece established the precedent for using White civilizations as the standard when evaluating other traditions: "...we may draw on the familiar to understand the unknown" (108). Not only does this portrayal as 'other' preclude Egypt from ever being perceived as entirely valid by future readers, this system of White-based evaluation ultimately dooms all non-White nations to a perpetual state of exoticism. Ultimately, Herodotus' biased representation of non-White traditions sets the stage for European 
colonialism, justifying subjugation by virtue of inherent White superiority.

While misrepresentation can have far-reaching effects, exclusion can be equally detrimental. As previously stated, the public's perception of a group directly impacts how those people are able to function in society. When a group is perceived accurately and positively, they are more likely to be accounted for in political legislation and benefit fully from the privileges promised in their respective society. Conversely, misrepresentation causes the opposite effect. If a person claims to speak for a group, but fails to do so effectively, his false narrative may negatively impact that group's social standing. A similar impact is caused if certain facets of a group are excluded from the discourse. The result is erasure, which effectively delegitimizes experiences and results in disenfranchisement from legislative actions and increased social vulnerability. If a group is not recognized, they cannot be protected from injustices.

Wollstonecraft's $A$ Vindication on the Rights of Woman is guilty of erasure on a massive scale as she purports to speak on behalf of all women while effectively ignoring women of color generally and Black women in particular. Throughout the text, she repeatedly cites lack of education as the biggest hurdle between women and equality, claiming that the discriminatory treatment women receive from men is justified due to women's alleged ignorance. She follows this with the assertion that educated women who are independent providers are more deserving of respect than other women: "The woman who owns her own bread by fulfilling some duty deserves more respect than the most accomplished beauty" (Wollstonecraft 88.) This argument directly equates a woman's worth to her education level, a claim which dehumanizes all women who have not received formal schooling, but especially impacts Black women.

Presumably, Wollstonecraft does not intend to negatively affect any woman through her work; but, because she clearly writes this piece with only White women in mind, yet presents it as applying to all women, her claims about education simultaneously disregard and actively harm Black women. While White women are feasibly able to go to school as evidenced by Wollstonecraft's own education, Black women remain socially and legally barred from doing so. Therefore, under Wollstonecraft's framework of equating humanity to schooling, Black women at that time are doomed to remain sub-human and deserving of whatever mistreatment they receive. This type of rhetoric sets the groundwork for White feminism which has a pattern of excluding women of color from its advocacy. Although White feminists rarely present themselves as explicitly against women of color, the means by which the feminists erase other women has a similar effect. By framing exclusive discourse as inclusive, those who are not properly represented are instantly delegitimized as society focuses on those in the forefront. As a result, the underrepresented group's issues are more easily disregarded when juxtaposed with the more visible topics. In this way, selective representation can be used to further erase an already overlooked people.

The original United States Constitution, and as a result, the country itself, was founded on a similar type of mass erasure. As evidenced by the document's iconic first line, "We the people..." the framers imply that their intention is to represent the entirety of the nation (U.S. Constitution). However, this is clearly untrue 
for several reasons, not the least of which is the fact that the public never gave the framers consent to create this document. Although women and people of color are neither given nor denied rights explicitly in the text, their exclusion leaves them vulnerable to future discrimination and delegitimizes the injustices which they are experiencing at the time of the Constitution's inception. A glaring example of this is the absence of the word "slavery" in the original document. Though the issue is implicitly addressed under the guise of importation rights and representation with vague statements such as "the migration or importation of such persons as any of the States now existing shall think proper to admit...", this omission has far-reaching impacts on the perception of the nation's history by future readers (U.S. Const. art. I, sec. 9). Because the document appears to function as a snapshot of the desires and concerns of America at that time, slavery's erasure from the text translates into its exclusion from historical discourse surrounding the nation's founding.

While the Constitution's erasure of Black people may not be with malicious intent, the American education system follows the Constitution's example by continuing to largely omit Black people from the curricula. The documentary, Revisionaries, depicts how American textbooks are created, showing the incredible nonchalance with which whole cultures and themes are edited or removed entirely. Arguably the most shocking scene in the film is when the school board votes to exclude all mentions of institutional racism from the social studies book, the book which once again is intended to function as a representation of American society. One of the board members addresses the insanity of this vote by scathingly saying, "We don't want to talk about discrimination" (Revisionaries.) The ramifications of such a decision are devastating. Not only does this sweeping erasure overlook centuries of continued suffering and hardship, it impacts how generations of students will perceive Black people.

Representation and perception directly impact a group's position in society. Therefore, when hundreds of thousands of students are never taught about systemic racism, yet are faced with daily images of police brutality against Blacks, urban centers full of minorities and under-education, and a host of other social issues that seem to be uniquely prevalent in Black and brown communities, these students are only able to understand society in a modern context or with the knowledge that America is the "land of the free," rather than recognizing these realities in the context of systemic inequality. As a result, in the eyes of a generation, minorities are once again viewed as the people who simply cannot 'get it together,' their struggles are delegitimized, and they are significantly less likely to receive the appropriate legislative intervention. Furthermore, this perception, when combined with Herodotus' Eurocentrism and Wollstonecraft's ideas about education and self-worth, creates a toxic society which validates White supremacy while dehumanizing millions of minorities. Once again all of this is accomplished not through explicitly aggressive language, but the absence of language all together.

Though literature and education are two important sources of representation, one of the largest sources of representation today in the U.S. is entertainment media. Regardless of the genre or plot, audiences view television and movies as reflections of the real world. 
Therefore, when viewers watch a story unfold on screen there is a certain level of truth that is assumed. As such, television and film are highly influential platforms for representation.

Because entertainment media functions as a massive mirror for audiences to peer into, those who cannot see themselves reflected are placed in a unique position. First, it is important to recognize the difference between erasure and absence. For example, if a show about the United States airs and only the U.S. is shown, Canadians will not complain about not appearing in the piece. Contrarily, if a show about North America airs and only the U.S. is shown, Canadians will then have been erased and will rightfully protest the piece. Erasure occurs when someone is omitted from their own narrative. Therefore, when entertainment media is framed as a mirror, but a consumer cannot find their reflection, there can be negative ramifications. Aside from the previously discussed societal harms of erasure, there are equally serious personal impacts as well.

Speaking from my experience as a Black girl, I understand how it feels to grow up without representation on television or in movies. Many of the insecurities I developed as a child about my hair are a direct result of my constant exposure to Eurocentric beauty standards. However, because of the recent unprecedented influx of minority representation, the issue is now shifting from one of erasure to one of misrepresentation. Now that I am older and more socially conscious, whenever I see Black people in entertainment, I am hyper-aware of the messages they are communicating. The continued lack of representation results in each image carrying inordinate significance.
Because of the importance of images in the media, I often find myself battling with the question of what constitutes 'good representation.' Does representation have to be all-inclusive in order to be considered valid? Especially in the entertainment arena, are Black characters prohibited from being flawed for risk of being perceived as offensive or problematic to the Black community? Should Hollywood no longer hire Black actors to play criminals and single mothers because those roles might be seen as stereotypical? Ultimately, does the need for positive and accurate representation actually translate into unreasonably high and limiting expectations? Is it such that the more desperately a group needs representation, the more difficult it becomes to do so satisfactorily?

Representation is a complicated and volatile endeavor. If done effectively, people can feel validated and emboldened. However, if done incorrectly, the results can be devastating. The only substantive solution to these harms is to increase the number of platforms available for underrepresented groups. This will lead to more diverse representation, highlight the countless realities within each community, and decrease the power each individual has to potentially devastate a people. It is impossible for anything to be perfectly inclusive, however the impact of erasure and misrepresentation will decrease substantially if opposing images are readily available.

\section{References}

Metni, Jawad. The Revisionaries. Independent Lens, 2012. 
Waterfield, Robin. Herodotus: the Histories. Translated by Carolyn Dewald, 1998th ed., N/A, Oxford University Press, 1998.

Wollstonecraft, Mary. "Early Modern Texts." A Vindication on the Rights of Woman with Strictures on Political and Moral Subjects, 1792, p. 88. 